\title{
PERBANDINGAN KEMAMPUAN REPRESENTASI MATEMATIK BERDASARKAN GAYA BELAJAR SISWA SMP
}

\author{
R. H. Yanti Silitonga* \\ Program Studi Pendidikan Matematika, Universitas Pattimura \\ Jalan Ir. M. Putuhena Unpatti, Poka, Ambon, Indonesia \\ "Email korespondensi: rhyanti_silitonga@yahoo.com
}

\begin{abstract}
ABSTRAK
Penelitian ini bertujuan untuk membandingkan kemampuan representasi matematik siswa berdasarkan gaya belajar yang dimiliki. Gaya belajar yang dimaksud dalam penelitian ini yaitu visual, auditori, dan kinestetik. Populasi penelitian adalah seluruh siswa kelas VII pada sebuah SMP di Bandung berjumlah 66 orang. Untuk menentukan gaya belajar siswa digunakan skala gaya belajar. Kemampuan representasi matematik siswa diperoleh dari tes berbentuk uraian. Berdasarkan hasil analisis data menggunakan One Way Anova diperoleh nilai signifikansi adalah 0,333 lebih dari 0,05 yang artinya tidak ada perbedaan yang signifikan kemampuan representasi matematik antara siswa yang memiliki gaya belajar auditori, visual, maupun kinestetik.
\end{abstract}

Kata kunci: representasi, visual, auditori, kinestetik,

\begin{abstract}
This study aims to compare students' mathematical representation abilities based on their learning styles. Learning styles referred to in this study are visual, auditory, and kinesthetic. The study population was all students of class VII at a junior high school in Bandung totaling 66 people. Determine student learning styles used learning styles scale. The students' mathematical representation ability was obtained from the test in the form of a description. Based on the results of data analysis using One Way Anova, the significance value is 0.333 more than 0.05 , which means that there is no significant difference in the ability of mathematical representation between students who have auditory, visual, and kinesthetic learning styles.
\end{abstract}

Keywords: representation, visual, auditory, kinesthetic.

\section{PENDAHULUAN}

Kemampuan representasi matematik merupakan salah satu dari enam kemampuan tingkat tinggi matematik yang harus dimiliki oleh seorang siswa. Kemampuan tingkat tinggi menurut NCTM (2000) yaitu kemampuan pemahaman matematik, kemampuan koneksi matematik, kemampuan komunikasi matematik, kemampuan penalaran matematik, kemampuan representasi matematik, dan kemampuan pemecahan masalah matematik. Sumarmo (2012) mengungkapkan bahwa kemampuan representasi matematik sangat penting agar siswa dapat berkomunikasi dan menyelesaikan masalah. Siswa yang menghadapi suatu 
masalah akan melakukan representasi internal dan representasi eksternal.

Representasi internal dilakukan oleh siswa di dalam pikirannya pada saat memikirkan masalah yang dihadapi, menerjemahkan masalah dalam bentuk yang lebih mudah diterima otak,memikirkan ide matematika menyelesaikan permasalahan yang dihadapi. Representasi eksternal dilakukan saat siswa mengkomunikasikan hasil dari representasi internalnya misalnya dalam bentuk simbol, tabel, grafik, gambar, pernyataan matematika, teks tertulis maupun kombinasinya (Sabirin, 2014). Siswa yang memiliki kemampuan untuk mentranslasi dari satu bentuk representasi ke bentuk representasi lain, mampu membuat kombinasi representasi dan bahkan mengubah ke bentuk representasi yang berbeda sangat membantu siswa memaksimalkan kemampuan matematikanya.

Kemampuan representasi matematik siswa dapat ditingkatkan dengan berbagai cara misalnya siswa sering diberikan latihan untuk membuat representasi dari masalah yang diberikan. Lebih lanjut, kemampuan representasi siswa juga dipengaruhi oleh guru. Guru yang mengajar dengan berbagai bentuk representasi yang sesuai dengan materi yang diajarkan dapat meningkatkan kemampuan representasi matematik siswa. Selain faktor guru, pengalaman dan pengetahuan siswa yang sebelumnya juga mempengaruhi. Gaya belajar yang dimiliki siswa kemungkinan mempengaruhi kemampuan representasi siswa.

Gaya belajar adalah gabungan dari cara siswa menerima, mengolah dan mengatur informasi yang diperoleh. Gaya belajar bersifat khas dan seringkali siswa tidak menyadari gaya belajar yang dimilikinya. DePorter dan Hernacki (1999) membagi gaya belajar ke dalam tiga jenis yaitu visual, auditori, dan kinestetik. Siswa dengan gaya belajar visual lebih mengutamakan indera mata dalam belajar. Siswa lebih mudah belajar dengan membaca sendiri daripada dibacakan oleh orang lain, melihat grafik/diagram/gambar dan melakukan sketsa sendiri. Siswa yang belajar lebih mengutamakan indera pendengaran adalah siswa yang memiliki gaya belajar auditory. Siswa bergaya belajar auditori menyenangi diskusi, berkomentar, lebih mudah mengerti ketika mendengarkan penjelasan lisan daripada membaca. Siswa yang memiliki gaya belajar kinestetik akan lebih menyukai pembelajaran yang melibatkan aktivitas fisik, dan ikut terlibat secara langsung sehingga mempunyai pengalaman sendiri.

Rose dan Nicholl (2009) memaparkan bahwa secara alamiah, setiap siswa memiliki satu jenis gaya belajar yang lebih dominan dari tiga jenis gaya belajar. Untuk setiap jenis gaya 
belajar yang berbeda dibutuhkan cara belajar yang sesuai dengan gaya belajar sehingga mengoptimalkan kemampuan matematik siswa maka siswa perlu mengetahui gaya belajar yang dimilikinya. Selain siswa, guru juga perlu mengetahui gaya belajar yang dimiliki siswa dan cara belajar yang tepat sesuai gaya belajar. Lebih lanjut, guru diharapkan dapat memfasilitasi siswa belajar sesuai dengan gaya belajar yang dimilikinya. Gaya belajar yang digunakan dalam penelitian ini adalah gaya belajar menurut De Porter dan Hernacki (1999) yaitu auditori, kinestetik, dan visual. Dari uraian diatas, rumusan masalah yang ingin diteliti yaitu apakah terdapat perbedaan yang signifikan kemampuan representasi matematik berdasarkan gaya belajar siswa.

\section{METODE PENELITIAN}

Penelitian ini adalah penelitian deskriptif dengan menggunakan desain cross sectional (Creswell, 2012). Populasi penelitian adalah seluruh siswa kelas VII SMP swasta di Bandung. Kelas VII terdiri dari tiga kelas yaitu kelas 7A, 7B dan 7C. Jumlah seluruh siswa kelas VII adalah 66 orang dengan masing-masing siswa di setiap kelas adalah 22 orang. Semua anggota populasi dijadikan sampel penelitian yaitu 66 orang.

Instrumen yang digunakan dalam penelitian ini adalah skala gaya belajar dan tes kemampuan representasi matematik. Skala gaya belajar diadaptasi dari DePorter and Hernacki (1999) dengan terlebih dahulu disesuaikan dengan bahasa sehari-hari agar siswa dapat memahami. Skala gaya belajar terdiri dari 24 pernyataan dengan 8 pernyataan masing-masing untuk menjaring gaya belajar visual, auditori, dan kinestetik. Skala gaya belajar divalidasi terhadapa lima ahli yang terdiri dari guru Bahasa indonesia, guru bimbingan konseling, dan guru matematika. Kemudian diujicobakan pada siswa yang bukan sampel penelitian untuk menguji kerterbacaan.

Tes kemampuan representasi matematik berbentuk uraian terdiri dari empat soal. Pedoman penskoran tes kemampuan representasi matematik berdasarkan pendapat Cai, Lane, dan Jakabesin (Silitonga, 2015). Tes kemampuan representasi matematik dengan menggunakan uji Q-Cochran diperoleh nilai Asymp. Sig. sebesar 0,075 lebih dari 0,05 sehingga tes kemampuan representasi matematik dinyatakan valid. Lebih lanjut, tes kemampuan representasi matematik di ujicobakan pada siswa yang bukan sampel penelitian kemudian hasil pengolahan data menggunakan AnatesV4 tipe uraian hasilnya adalah instrumen dinyatakan valid dan reliabel. 


\section{HASIL DAN PEMBAHASAN}

Berdasarkan hasil penelitian diperoleh dari 66 siswa yaitu 36 siswa bergaya belajar visual, 15 siswa bergaya belajar auditori, 15 orang bergaya belajar kinestetik. Persentase siswa yang memiliki gaya belajar yang paling banyak adalah siswa bergaya belajar visual yaitu $54,54 \%$, sedangkan persentase siswa yang memiliki gaya belajar auditori dan kinestetik memiliki jumlah yang sama yaitu 22,73\%. Tabel 1 menunjukkan karakteristik gaya belajar siswa.

Tabel 1. Gaya Belajar Siswa

\begin{tabular}{cccc}
\hline No & Gaya Belajar & Jumlah & \% \\
\hline $\mathbf{1}$ & Visual & 36 & $54,54 \%$ \\
$\mathbf{2}$ & Auditori & 15 & $22,73 \%$ \\
$\mathbf{3}$ & Kinestetik & 15 & $22,73 \%$ \\
& Jumlah & 66 & $100 \%$ \\
\hline
\end{tabular}

Berdasarkan tes kemampuan representasi matematis siswa diperoleh rata-rata kemampuan representasi matematik siswa bergaya belajar kinestetik yakni 50,33 dan merupakan rata-rata yang paling rendah dibandingkan dengan siswa bergaya belajar auditori dan visual. Rata-rata kemampuan representasi matematik siswa bergaya belajar auditori adalah 50,26 kemudian siswa bergaya belajar visual mencapai 57,30. Pada siswa kelompok visual, nilai representasi matematik siswa yang paling rendah adalah 26 dan paling tinggi adalah 96. Sedangkan siswa kelompok auditori, nilai siswa yang paling rendah adalah 30 sedangkan paling tinggi adalah 100. Nilai paling rendah pada kelompok kinestetik yakni 37 kemudian nilai paling tinggi adalah 74. Rangkuman data statistik disajikan pada Tabel 2.

Tabel 2 Rata-Rata Kemampuan Representasi Matematik

\begin{tabular}{lccccc}
\hline $\begin{array}{l}\text { Gaya Belajar } \\
\text { Siswa }\end{array}$ & N & Mean & SD & Min & Max \\
\hline Visual & 36 & 57,30 & 15,89 & 26,00 & 96,00 \\
Auditori & 15 & 57,26 & 20,12 & 30,00 & 100,00 \\
Kinestetik & 15 & 50,33 & 9,58 & 37,00 & 74,00 \\
& 66 & 55,71 & 15,86 & 26,00 & 100,00 \\
\hline
\end{tabular}

Untuk mengetahui apakah terdapat perbedaan yang signifikan kemampuan representasi matematik berdasarkan gaya belajar siswa maka dilakukan analisis data dengan menggunakan metode One Way Anova dengan taraf signifikasi $\alpha=5 \%$. Dari uji normalitas dengan Shapiro Wilk karena jumlah siswa pada setiap kelompok gaya belajar kurang dari 50 orang diperoleh 
nilai signifikan kemampuan presentasi matematik siswa bergaya belajar visual, auditori, dan kinestetik secara berturut-turut yaitu 0,078, 0,438, dan 0,226. Karena nilai signifikansi lebih dari 0,05 maka ketiga kelompok gaya belajar berdistribusi normal. Selanjutnya, dilakukan uji homogenitas diperoleh nilai signifikansi pada uji levene yakni 0,108 lebih dari 0,05 artinya ketiga kelompok gaya belajar homogen.

Nilai signifikansi dari uji One Way Anova adalah 0,333 lebih dari 0,05 sehingga diperoleh kesimpulan tidak terdapat perbedaan yang signifikan kemampuan representasi matematik berdasarkan gaya belajar siswa (visual, auditori, dan kinestetik). Tidak terdapat perbedaan kemampuan representasi matematik pada ketiga kelompok gaya belajar kemungkinan karena guru dalam mengajar matematika cenderung sama dalam memfasilitasi siswa sesuai gaya belajarnya. Hasil penelitian ini sejalan dengan hasil penelitian Rubianus (2013) yang menyatakan tidak ada perbedaan yang signifikan hasil belajar matematika siswa pada kelompok bergaya belajar kinestetik, auditori, maupun visual.

\section{KESIMPULAN}

Berdasarkan hasil penelitian dapat disimpulkan bahwa:

1. Tidak terdapat perbedaan yang signifikan kemampuan representasi matematik antara siswa bergaya belajar visual, auditori, maupun visual.

2. Siswa yang memiliki gaya belajar visual berjumlah paling banyak yaitu 36 orang atau $54,54 \%$. Siswa yang memiliki gaya belajar kinestetik berjumlah 15 orang, sedangkan siswa yang bergaya belajar auditori berjumlah sama yaitu 15 orang.

3. Rata-rata kemampuan representasi matematik siswa hanya mencapai 55,71.

\section{REKOMENDASI}

Dari hasil penelitian ini beberapa hal yang diharapkan yakni:

1. Bagi guru matematika, sangat penting untuk mengetahui gaya belajar yang dimiliki oleh siswa dan apabila ada gaya belajar yang dominan dapat dijadikan sebagai bahan pertimbangan dalam memilih dan mengembangkan bahan ajar, dan media pembelajaran.

2. Bagi siswa, harus mengetahui gaya belajar yang dimiliki kemudian berusaha untuk belajar dengan cara-cara yang sesuai dengan gaya belajarnya sehingga dapat meningkatkan kemampuan matematik. 
3. Bagi sekolah, lebih mengoptimalkan penyediaan sarana dan prasarana untuk memfasilitasi siswa belajar sesuai dengan gaya belajarnya.

4. Bagi peneliti selanjutnya, melakukan penelitian yang dapat meningkatkan kemampuan representasi matematik siswa sesuai dengan gaya belajarnya.

\section{REFERENSI}

Creswell, J. W. (2012). Educational research: Planning, conducting, and evaluating quantitativCreswell, J. W. (2012). Educational research: Planning, conducting, and evaluating quantitative and qualitative research. Educational Research (Vol. 4). https://doi.org/10.1017/CBO97811. In Educational Research.

DePorter, B. dan Hernacki, M. (1999). Quantum learning membiasakan belajar nyaman dan menyenangkan, terjemahan Ary Nilandari. Kaifa.

NCTM. (2000). Principles and Standards for School Mathematics Overview. Journal of Equine Veterinary Science.

Rose, C. dan Nicholl, M. (2009). Accelerated Learning for The Century Cara Belajar Cepat Abad XXI Terjemahan Ahimsa. Nuansa.

Sabirin, M. (2014). Representasi dalam Pembelajaran Matematika. Jurnal Pendidikan Matematika. https://doi.org/10.18592/jpm.v1i2.49

Silitonga, R. H. Y. (2015). Penerapan Accelerated Learning untuk Meningkatkan Kemampuan Pemecahan Masalah dan Representasi Matematis Siswa SMP Universitas Pendidikan Indonesia | repository.upi.edu | perpustakaan.upi.edu.

Sumarmo, U. (2012). Pendidikan karakter serta pengembangan berfikir dan disposisi matematik dalam pembelajaran matematika. Seminar Pendidikan Matematika. 